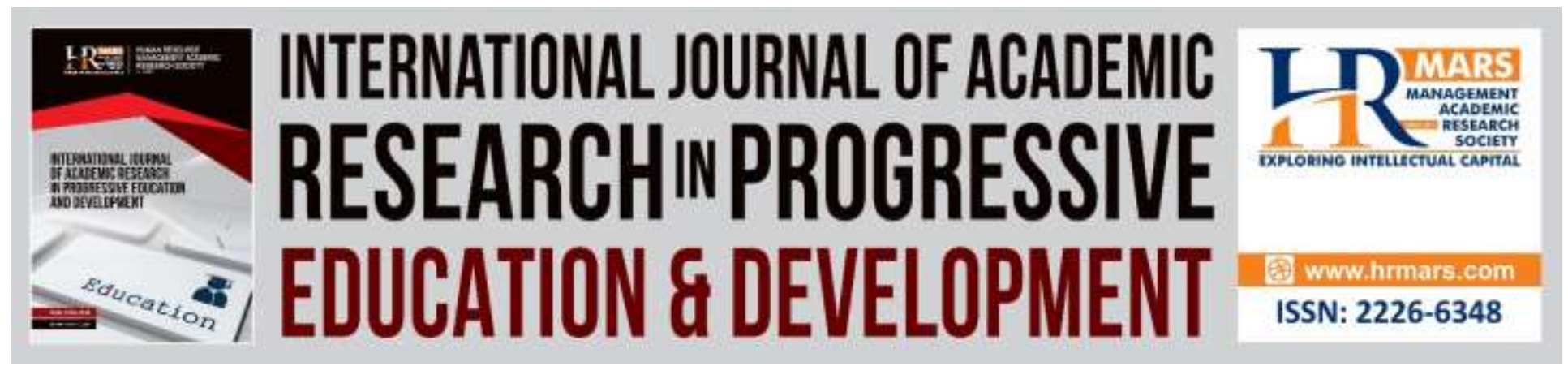

\title{
Understanding of Lecturers' Verbal Interaction in Teaching of Malay Language at Institute of Teacher Education
}

\section{Zarien Nurlieyana Aminuddin, Azhar Md. Sabil, Abdul Rasid Jamian}

To Link this Article: http://dx.doi.org/10.6007/IJARPED/v8-i4/6899

DOI:10.6007/IJARPED/v8-i4/6899

Received: 15 October 2019, Revised: 30 October 2019, Accepted: 11 November 2019

Published Online: 30 November 2019

In-Text Citation: (Aminuddin et al., 2019)

To Cite this Article: Aminuddin, Z. N., Sabil, A. M., \& Jamian, A. R. (2019). Understanding of Lecturers' Verbal Interaction in Teaching of Malay Language at Institute of Teacher Education. International Journal of Academic Research in Progressive Education and Development, 8(4), 997-1003.

Copyright: (C) 2019 The Author(s)

Published by Human Resource Management Academic Research Society (www.hrmars.com)

This article is published under the Creative Commons Attribution (CC BY 4.0) license. Anyone may reproduce, distribute, translate and create derivative works of this article (for both commercial and non-commercial purposes), subject to full attribution to the original publication and authors. The full terms of this license may be seen at: http://creativecommons.org/licences/by/4.0/legalcode

Vol. 8(4) 2019, Pg. 997 - 1003

http://hrmars.com/index.php/pages/detail/IJARPED JOURNAL HOMEPAGE

Full Terms \& Conditions of access and use can be found at http://hrmars.com/index.php/pages/detail/publication-ethics 


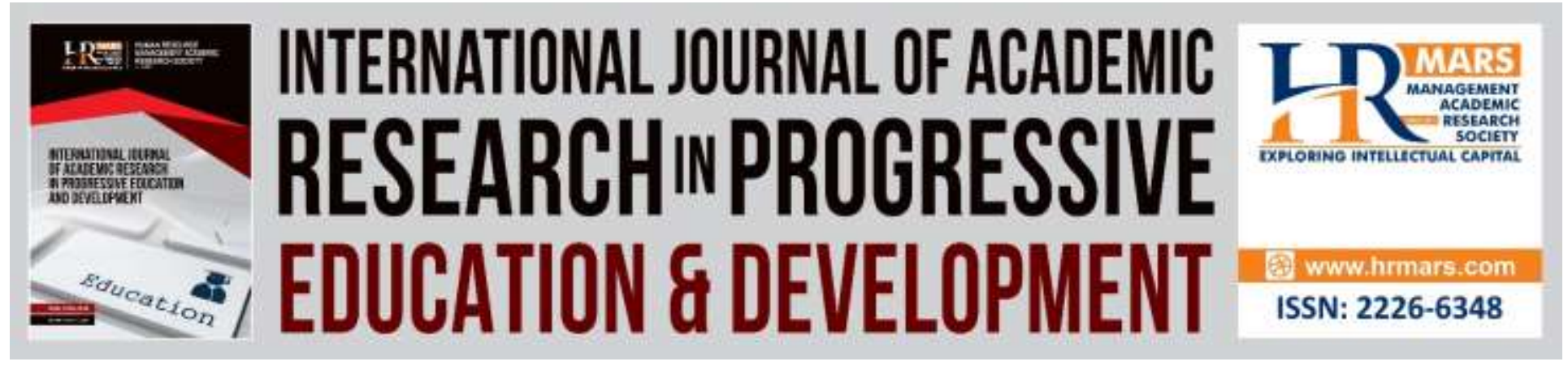

\title{
Understanding of Lecturers' Verbal Interaction in Teaching of Malay Language at Institute of Teacher Education
}

\author{
Zarien Nurlieyana Aminuddin, Azhar Md. Sabil, Abdul Rasid \\ Jamian \\ Department of Languange and Humanities Education, Faculty of Education Studies \\ University Putra Malaysia, MALAYSIA \\ Email: eizlieyana@gmail.com
}

\begin{abstract}
Verbal interaction is the main medium of communication for language educators in each educational institution. Lecturers need to enhance a verbal communication skills and be fluent in language. A language teaching, especially in the field of Malay as the official language, is a key element of oral delivery in a teaching method. The practice of teaching transformation creates a critical, creative and innovative graduate experience. The implementing of language teaching involves of three basic skills which includes reading, writing and oral skills. This paper discuss clearly about the lecturers' understanding of oral skills is an oral presentation in the teaching of lecturers when interacting with students. The culture of oral interaction used by language education lecturers has always been the best practice in teaching and learning. This study uses qualitative method which is the interview method. The lecturers' teaching is not just a result of language proficiency but also the lecturers' communication as a teaching knowledge. Therefore, proper verbal interaction is implemented in line with the language teaching creativity in order to produce a quality of teacher in communication.
\end{abstract}

Keywords: Verbal Interaction, Lecture Verbal, Oral Skill Teaching, Higher Education.

\section{Introduction}

A lecturers not only carry the responsibility to educate and impart knowledge but also contribute to the generation of the heirs who have good academic achievements and also supported by praised values and morals. Working as the lecturer at the Institute of Teacher Education (IPG) is looks easy, but the burden of their work must in line with current teaching. Teaching at the IPG should go beyond the current skills and expertise. Lecturers also need to adopt an educational technology approach which is compatible with a current teaching. Teaching in Malay language is the national language, national language and official language of the country as enshrined in Article 152 of the Federal Constitution and the Education Act 1996. The policy of National 
Vol. 8, No. 4, 2019, E-ISSN: 2226-6348 @ 2019 HRMARS

Education (1979), however, clearly outlined the implementation of national education strategies in its first clause that aims to make the National Language is the primary language. Malay language is not only guaranteed under Article 152 of the Malaysian Constitution, but it follows to the National Education Policy.

The lecturers are responsible to educate students and guiding them to enhance their knowledge. The lecturers are classified into facilitate learning orientation to see teaching as a facilitative process in order to help students develop critical problem solving and thinking skills (Sihes \& Sidin, 2008). The students are given the opportunity to actively participate in each learning session and they assisted by the instructor which called as a facilitator (Hashim et al, 2003). The effectiveness of lecturers in carrying out their duties and responsibilities of educating and delivering teaching depends on a variety of common learning factors (Sihes \& Sarimin, 2009).

\section{Verbal Interaction in Learning}

The verbal interaction is not only a channel for information but can be known as a teaching and learning tool. A teacher are prefers to use interaction as a medium of language. The types of verbal interaction in teaching and learning are greetings, explanations, questions, directional control and sarcasm (Balaki \& Othman, 2007). A verbal interaction has the potential to produce a quality of teaching skills. The development of teaching is able to produce an optimal learning among students. In the process of speaking skills is very important without significant teaching and learning processes and their mastery seems natural (Stubbs, 1930; Balaki, 2003). The mastery of spoken skills enables communication to occur which often involves high verbal interaction.

An oral interaction is important in ensuring the lecturer's life running smoothly. In other words, an oral interaction is not only the presentation of instructional information but it also builds and maintains the relationships, influences and persuades, tells something, asks questions, informs and analyzes (Balaki, 2003). An effective communication not only helps us solve problems but also helps to improve the relationships. Communication specialists believed that a poor communication skills is the main cause of most problems and the effective communication is the solution to the most problems (Pearson, 2000).

A lecturer needs to be prepared for the teaching creativity during a lecture session. This shows that a lecturer not only needs to prepare in terms of lesson plans and teaching aids, but they also needs to practice a teaching method with a good communication skills to attract the students. Otherwise, teaching at that time will make students feels bored and less focused and focused during the teaching process. Verbal interactions will be most effective method when the teachers presented a clear speech, enthusiastic speech and two-way communication.

The oral presentation of an educators at educational institution that is interesting in teaching is very helpful in the mastery of the Malay language among students. The same goes for verbal and non-verbal communication (Radhiah, 2012). A lecturer have a variety of oral teaching styles. As a consequences, the student communication between lecturer and student is a useful process of developing ideas and discussion. A communication between professors and students that good 
communication skills among students is very important for facilitating their placement in the work environment (Rahim \& Abd. Rahim, 2013).

In addition to that, a verbal interactions have a significant impact on students' knowledge. The way of students' ability to understand and receive their knowledge is very different. This larger and the most significant impact translates how the importance of oral skills to the students from an early age (Jamian \& Othman, 2013). An effective oral interaction in the classroom is a medium for mastering students' oral skills. Social relationships between lecturers and students can be formulated warmly in the context of teaching and learning through the lecture methods and classroom discussions. The most important verbal interaction in presenting the content depends on the methods and methods presented by the lecturers. Thus, the teaching method can create an active opportunity for students to interact more openly.

\section{Methodology}

A qualitative research was conducted to explore some related issues, understanding on the phenomena and answer some questions through the information of analysis (Pardi, 2010). This studies use a structured interviews to further explain the phenomenon and the problems of the study (Yahya et al. 2006). Besides, this method also involves an accurate vision and writing of a phenomenon that exists naturally by focusing to the causes and effects or the related relationships (Anand, 2002).

\section{Research Analysis}

An understanding on oral interaction has a multiple perspectives to explain the meaning on oral interaction in teaching. PK1's view of oral comprehension is as follows;

PK1

Oral interaction involves of two things: speaking and listening. This is the basic things of oral interaction. While teaching the students, the teachers or lecturers must have this skills either in the form of oral, reading and writing. When we are talking about oral, we must look into two aspects which are speaking and listening. Listening part can be achieved when we give them a clear instructions. If the instruction is not clear, our instructions will give them a different answer. Then, a speaking part, what do I say is what is important I need them to give an opinion in order to develop these oral skills. Oral is a basic skill. In a high level of speeches, it involves a concept, giving an opinion or even giving some concept and therefore can be debated.

PK2

This oral interaction is not just a communication but it involves an understanding of each other. They have a lot of people and the people must have the ability to understand from there. What we say students will be understood by the understanding from their reactions, the way of their responds, the interrogation between them. These oral interactions make the students understand of what we are saying and misunderstood will not be happened.

PK3

(i) ... so, the learning method in IPG is for a person who will become a teachers. These are students who will give a knowledge and will work as a teachers in the schools. 
(ii) Oral interaction is the easiest ways to do such as explaining something. The lecturers will convey the knowledge depending on their own creativity. Some of them will do an explanations, stories, jokes or asking an opinions. So, the meaning of oral interaction is the speaking skills, our conversation using a language for communication. The way of we communicate involves talking, directing, telling, telling, asking. That is called as oral interaction.

PK4

Oral interaction involves the spoken language of conversation. The utterance we use in everyday conversation. Oral involves the language of our pleasant-mannered, the tone, and the intonation of teaching. So the oral interactions belongs to listening and speaking. We use our own communication and listening. In the context of teaching skills, the lecturers also have a functions of brings an information to the students. When the lecturers speaks, the students will listening to the lecturers.

In PK1's opinion, the oral interaction involves of two important things in language skills, especially in oral skills. The main skills in teaching are oral skills which involves listening and speaking skills. The element of oral skills consists of oral interactions which involves of speaking and listening. Each form of instructional interaction given by the lecturer such as the assignment or explanation will be clearly understood.

Besides, oral interaction involves of utterance that are given in the form of student feedback on the topic of teaching. PK2's opinion, explaining that understanding of oral interactions involves the students' understanding of PdP information from the lecturers.

Students' understanding of the topic of teaching can be seen through the interaction of the interrogation with the lecturer. A clear explanations by the lecturers can be evaluated using a verbal and non-verbal language delivered by engaging the student body language.

Next, the understanding of oral interactions described by the participants of the PK3's and PK4's studies is related to the creativity of the lecturers and the proficiency in delivering the information. According to PK3, oral interactions involving an activities of suggestion of opinions and giving an explanation. PK3's opinion makes it clear that lecturers use the language arts such as humor, questioning, story-telling and directing. Therefore, an oral interaction also plays an important role in the presence of language elements including tone, intonation and pronunciation. In the context of teaching, the lecturers' oral interactions have a great impact in delivering the information and passing on useful information to generate a human capital.

\section{Conclusion}

As a conclusion, the teaching process involves the creativity of a lecturer's in delivering their teaching skills. A teacher or lecturer should consider an appropriate teaching technique in order to help students to solve the problems that arise in this field. Besides, they should improve their skills and teaching quality such as empower and enrich their teaching skills or strategies. This is because, by empowering of skills can enhance their knowledge in the field of teaching (Azizi Yahya, Ramli \& Ahmad (2007). 
INTERNATIONAL JOURNAL OF ACADEMIC RESEARCH IN PROGRESSIVE EDUCATION AND

DEVELOPMENT

Vol. 8, No. 4, 2019, E-ISSN: 2226-6348 @ 2019 HRMARS

\section{Corresponding Author}

Insert complete information of corresponding author including name, affiliation, country, email ID, Address.

Zarien Nurlieyana Aminuddin, Jabatan Pendidikan Bahasa dan Kemanusiaan, Fakulti Pengajian Pendidikan, Universiti Putra Malaysia, 43400 Serdang Selangor

\section{References}

Sihes, A. J. H., \& Sidin, Z. H. (2008). "Konsepsi Pengajaran Pensyarah dan Hubungannya dengan Persekitaran Pengajaran Pensyarah", Jurnal Teknologi jil.48 no.239.

Sihes, \& Sarimin, S. A. (2009), "Keutamaan Ciri-Ciri Pengajaran Pensyarah Yang Baik Daripada Persepsi Pelajar Di Universiti Teknologi Malaysia, Skudai, Johor." (2009).

Aman, I. (2010), Analisis Wacana, Penerbit Universiti Kebangsaan Malaysia, Bangi.2010.

Baba, I. (2009) Keberkesanan Pengajaran dan Pembelajaran dan Kaitan terhadap prestasi akademik pelajar UTHM, Tesis yang tidak diterbitkan PhD Geran jangka pendek, Universiti Tun Hussein Onn Malaysia m/s 229-235.

Long, J. (2010), Pengajaran dan Pembelajaran Bahasa Melayu, Kaedah dan Pembelajaran Bahasa Melayu, Penerbitan Universiti Kebangsaan Malaysia, Bangi Selangor. .

Mahamod, Z., \& Lim, N. R. (2016). Kepelbagaian kaedah penyoalan lisan dalam pengajaran guru Bahasa Melayu: kaedah pemerhatian. Jurnal Pendidikan Bahasa Melayu, 1(1), 51-65.

Rahim, N. A. A., \& Abd.Rahim, N. (2014). Strategi komunikasi lisan secara formal dalam kalangan pelajar kejuruteraan. Procedia-Social and Behavioral Sciences, 134, 382-388.Nor Aishah Abdul Aziz, Mohd Zolkifli Abd Hamid, Ismail Saliyan \& Nurul Izzati Mohd Fuad, Kualiti Pendidikan Di Ipt: Pendekatan Spiritual DalamPendidikan Berasaskan Hasil (OBE), 2nd International Seminar on Quality and Afforadle Education 2013 (ISQAE2013)

Hashim, S., Razali, M., \& Jantan, R. (2003), Psikologi Pendidikan, Kuala Lumpur: PTS Publishing Sdn. Bhd.

Mohamad, S., Jasmi, K. A. (2011), Penyeliaan Guru dalam Pengajaran \& Pembelajaran, Edisi ke 1, Penerbit UTM Press, Universtiti Teknologi Malaysia, Johor Bahru.

Salim, S. S. S., Jusoh, A. Z., Bistaman, M. N., Arip, M. A. S. M., Mustafa, M. B., \& Nasir, R. (2011). Peranan Kecerdasan Emosi dan Faktor Ciri-ciri Pekerjaan ke Atas Kepuasan Bekerja Dalam Profesion Perguruan. Jurnal Pengajian Pendidikan.

Thomas, S. J. (2001), The Principalship:A Reflective Practice Perspective I Edisi ke-4. Boston: Allyn and Bacon

Baki, R., \& Othman, Y. (2007), Interaksi lisan pengajaran dan pembelajaran Bahasa Melayu: potensi yang terabai, Pertanika Journal of Social Sciences \& Humanities (Volume15, No 2, 2007)

Aziz, S. H. A. (2009). Siri Pendidikan Guru: Bahasa Melayu II. Selangor Darul Ehsan: Laser Press Sdn Bhd.

Isa, S. H. (2015), Penguasaan Lisan Bahasa Melayu Pelajar dalam kalangan prauniversti, Tesis ljazah sarjana Sastera, Universiti Putra Malaysia. 
INTERNATIONAL JOURNAL OF ACADEMIC RESEARCH IN PROGRESSIVE EDUCATION AND

DEVELOPMENT

Vol. 8, No. 4, 2019, E-ISSN: 2226-6348 @ 2019 HRMARS

Yusri, G., Rahimi, N. M., Shah, P. M., Wah, W. H., \& Hassan, A. T. (2012). Penggunaan Strategi Belajar Bersama Rakan Dalam Kalangan Pelajar Kursus Bahasa Arab Di Universiti Teknologi Mara (UiTM). Journal of Educators \& Education/Jurnal Pendidik dan Pendidikan, 27.

Osman, Z., \& Adzharuddin, N. A. (2015), Pengaruh Visual dan Verbal dalam Iklan Kempen terhadap emosi, Journal of Education and Social Sciences, Vol. 2, (Oct) ms 51-55. 